\title{
JNPH
}

Volume 5 No. 1 (Juli 2017)

(C) The Author(s) 2017

\section{PEMANFAATAN SAMPAH ORGANIK SEBAGAI BAHAN DASAR PEMBUATAN BIOGAS DI WORKSHOP KESEHATAN LINGKUNGAN BENGKULU}

\author{
UTILIZATION OF ORGANIC WASTE AS A BASIC MATERIAL MAKING OF \\ BIOGAS IN WORKSHOP OF ENVIRONMENTAL HEALTH BENGKULU
}

\author{
HAIDINA ALI \\ JURUSAN KESEHATAN LINGKUNGAN POLTEKKES KEMENKES BENGKULU \\ Email: alimanafh@gmail.com
}

\begin{abstract}
ABSTRAK
Latar Belakang : Sampah selalu timbul menjadi persoalan rumit dalam masyarakat yang kurang memiliki kepekaan terhadap lingkungan. Limbah sampah organik (sayuran) yang tidak terpakai menjadi salah satu masalah lingkungan yang sampai saat ini belum dapat ditangani dengan cepat dan tepat. Sampah yang tidak dikelola dengan baik dapat menimbulkan bau tidak sedap dan menjadi tempat berkembangnya berbagai macam penyakit. Pengolahan sampah organik (sayuran) menjadi biogas dapat mengurangi masalah sampah. Penelitian ini bertujuan untuk mengetahui perbedaan lama waktu terbentuknya biogas sampah organik dengan penambahan biostarter kotoran sapi dan $\mathrm{EM}_{4}$. Metode penelitian : Metode yang digunakan adalah eksperimen murni dengan desain penelitian "Posttest Only Group Design With Control" dan dianalisis dengan uji statistik yaitu One Way Anova yang dilanjutkan dengan uji Bonferroni. Hasil : Ada perbedaan yang lama waktu terbentuknya biogas sampah organik dengan perlakuan yaitu penambahan $\mathrm{EM}_{4}$ sebanyak $200 \mathrm{ml}$ dan $250 \mathrm{ml}$ serta pada kelompok kontrol, dan diantara ketiga perlakuan yang paling efektif dalam mempercepat pembentukan biogas adalah pada perlakuan ke-2 dengan penambahan $\mathrm{EM}_{4}$ sebanyak $250 \mathrm{ml}$. Dapat disimpulkan hasil dari penelitian ada perbedaan lama waktu terbentuknya biogas sampah organik dengan penambahan biosaterter kotoran sapi $2 \mathrm{~kg}, \mathrm{EM}_{4}$ sebanyak $200 \mathrm{ml}$ adalah 13 hari, dan $250 \mathrm{ml}$ adalah 11 hari serta pada kelompok kontrol. Saran : Diharapkan bagi masyarakat dapat memanfaatkan sampah organik sebagai bahan untuk membuat biogas serta memanfatkan kotoran sapi sebagai pemicu untuk mempercepat terbentuknya biogas dan dapat mengurangi penggunaan biogas sebagai bahan bakar minyak (BBM) menjadikan biogas sebagai bahan bakar alternatif pengganti bahan bakar lainnya.
\end{abstract}

Kata Kunci : sampah organik, biogas, workshop

\begin{abstract}
Background: Garbage always arises as a complex problem in a society with less environmental sensitivity. Unused organic waste (vegetable) becomes one of the environmental problems that until now can not be handled quickly and precisely. Waste that is not managed properly can cause is bad smell and the place could be the development of various diseases. Processing organic waste (vegetables) into biogas can reduce the problem of waste. This study aims to determine the difference in the time period of biogas organic waste formation with the addition
\end{abstract}


of biostarter of cow dung and EM4. Metode of the research: The method used is a pure experiment with research design "Posttest Only Group Design With Control" and analyzed by statistical test that is One Way Anova followed by Bonferroni test. Result: There is a difference in the time of biogas formation of organic waste by the treatment of $200 \mathrm{ml}$ and $250 \mathrm{ml}$ of EM4 addition and in the control group, and among the three treatments that are most effective in accelerating the formation of biogas is in the 2nd treatment with the addition of EM4 as much as $250 \mathrm{ml}$. It can be concluded that the result of the research shows that there is a difference in the time period of biogas organic waste with the addition biosatnerter of $2 \mathrm{~kg}$ cow dung, EM4 as much $200 \mathrm{ml}$ is 13 days, and $250 \mathrm{ml}$ is 11 days and in the control group. Suggestion: It is expected that the community can utilize organic waste as a material to make biogas and cattle dung as a trigger to accelerate the formation of biogas and can reduce the use of biogas as fuel oil (BBM) to make biogas as alternative fuel for other fuel burns.

Keywords: organic waste, biogas, workshop

\section{PENDAHULUAN}

Masalah krisis energi yang terjadi di Indonesia terus meningkat. Salah satu gejala krisis energi yang terjadi akhir-akhir ini yaitu kelangkaan Bahan Bakar Minyak (BBM). Kelangkaan terjadi karena tingkat kebutuhan Bahan Bakar Minyak (BBM) sangat tinggi dan selalu meningkat setiap tahunnya. Sementara itu, minyak bumi bahan baku pembuatan BBM berjumlah terbatas dan membutuhkan waktu berjuta-juta tahun untuk proses pembentukannya. Hal ini secara tidak langsung akan berdampak terhadap perekonomian Negara, terutama bagi negara miskin dan berkembang, termasuk Indonesia (Wahyuni, 2011).

Sumber energi alternatif cukup tersedia misalnya energi matahari dimusim kemarau atau musim kering, energi angin dan air. Namun bagi sumber energi lain belum kelihatan signifikan, adanya regulasi dibidang energi seperti kenaikan tarif listrik, harga LPG, dan minyak tanah tentu membawa dampak bagi perekonomian masyarakat, sumber energi yang murah dan ramah lingkungan adalah biogas.

Energi terbaru lain yang dapat dihasilkan dengan teknologi tepat guna yang relatif sederhana, mudah diperoleh, dapat diperbaharui dan sesuai untuk daerah perdesaan adalah energi biogas dengan memproses limbah bio di dalam alat kedap udara yang disebut digester. Biogas diperoleh dengan cara memanfaatkan limbah berupa kotoran hewan ternak bahkan tinja manusia. selain itu pembuatan biogas juga dapat diperoleh dengan menambahkan campuran bahan dari limbah sampah organik (sayuran). Sampah selalu timbul menjadi persoalan rumit dalam masyarakat yang kurang memiliki kepekaan terhadap lingkungan. Begitu banyak kondisi tidak menyenangkan akan muncul seperti bau tidak sedap, lalat beterbangan, dan gangguan berbagai penyakit. Campuran beragam jenis sampah organik dan anorganik yang terdapat dalam tumpukan sampah akan menyulitkan proses penguraian secara alami.

Dampak negatif sampah mungkin tidak bisa dihilangkan secara tuntas sampai ke akarnya. Namun, usaha pengolahan sampah yang telah dilakukan berbagai pihak turut memberikan kontribusi guna menanggulangi sampah. Salah satu peran nyata masyarakat bisa tersalurkan melalui penggunaan produk berbahan baku sampah maupun hasil daur ulangnya dikehidupan sehari-hari.

Limbah sampah organik (sayuran) yang tidak terpakai menjadi salah satu masalah lingkungan yang sampai saat ini belum dapat ditangani dengan cepat dan tepat. Sampah yang tidak dikelola dengan baik dapat menurunkan etika dan estetika lingkungan, menimbulkan bau tidak sedap, dapat menjadi tempat berkembangnya berbagai macam penyakit, dan dapat memicu pemanasan global (Chandra, 2012).

Pengelolahan sampah organik (sayuran) menjadi biogas dapat mengurangi masalah 
sampah. Biogas yang dihasilkan dari sampah organik (sayuran) tidak berbeda dengan biogas yang dihasilkan dari bahan lainnya. Sementara itu sampah organik (sayuran) dapat dijadikan bahan untuk pembuatan biogas dengan mencampurkan kotoran hewan seperti sapi untuk mempercepat proses fermentasi. Cara ini diharapkan dapat mengurangi volume sampah yang semakin melimpah. Bila pengelolahan sampah berkembang baik, lingkungan akan menjadi sehat dan bersih (Alex S, 2012).

Kandungan biogas didominasi sebagai zat metana $\left(\mathrm{CH}_{4}\right)$ yang merupakan hasil sampingan dari proses dekomposisi mikroba hasil fermentasi. Mikroba tersebut merupakan bakteri pembentuk metana yang banyak terdapat dalam tubuh hewan ruminansia seperti kerbau, sapi, domba, kambing, dan lain-lain. Secara prinsip pembuatan biogas sangat sederhana, dengan memasukan subsrat (kotoran hewan) kedalam unit pencernaan (digester), ditutup rapat dan selama beberapa waktu biogas akan terbentuk dan selanjutnya dapat digunakan sebagai sumber energi.

Di Indonesia peternakan sapi rata-rata memiliki dua sampai lima ekor sapi dengan lokasi yang tersebar. Kondisi demikian menyebabkan penanganan limbah kotoran hewan sulit dilakukan. Sapi yang mempunyai bobot badan $450 \mathrm{~kg}$ mengasilkan limbah berupa kotoran dan urine kurang lebih $25 \mathrm{~kg}$ per ekor per hari. Limbah kotoran hewan terdiri atas limbah padat, limbah cair dan limbah gas. Penanganan limbah yang baik sangat penting karena dapat memperkecil dampak negatif terhadap lingkungan, seperti polusi tanah, air, udara dan penyebaran penyakit menular (Wahyuni, 2011).

Jumlah penduduk di Indonesia yang besar dengan tingkat pertumbuhan $1,49 \%$ per tahun mengakibatkan bertambah banyaknya volume sampah yang dihasilkan. Pada tahun 2013 jumlah penduduk di Indonesia sebanyak 250 juta penduduk, dengan rata-rata sampah yang dihasilkan sebanyak $0,75 \mathrm{~kg} /$ orang/hari. Setiap harinya sampah yang dihasilkan penduduk Indonesia sebanyak $187.500 .000 \mathrm{~kg} / \mathrm{hari}$. Pola konsumsi masyarakat memberikan kontribusi terhadap timbulan jenis sampah yang semakin beragam (Badan Pusat Statistik, 2013).

Potensi limbah sampah organik (sayuran) untuk dimanfaatkan sebagai bahan pembuatan biogas sebenarnya cukup besar, namun belum banyak dimanfaatkan bahkan dapat menimbulkan masalah pencemaran dan kesehatan lingkungan yang dapat merugikan kesehatan sekitar (Setiawan, 2007).

Berdasarkan latar belakang diatas maka peneliti tertarik untuk melakukan penelitian "Pemanfaatan sampah organik sebagai bahan dasar pembuatan biogas di Workshop Kesehatan Lingkungan".

\section{BAHAN DAN CARA KERJA}

\section{Alat}

Alat yang digunakan dalam penelitian :

1) Derigen volume 35 liter.

2) Selang plastik ukuran $3 / 4$ inch

3) Kantong plastik.

4) Pentil ban sepeda motor.

5) Pisau.

6) Literan.

7) Ember plastik.

8) Timbangan.

9) Batang kayu ( Pengaduk )

10) Corong plastik

11) Gelas ukur $1000 \mathrm{ml}$

Bahan yang digunakan dalam penelitian :

1) Keseluruhan kotoran sapi yang digunakan $22 \mathrm{~kg}$.

2) Keseluruhan sampah organik (sayuran) $55 \mathrm{~kg}$.

3) Air biasa 154 liter.

4) $\mathrm{EM}_{4} 450 \mathrm{ml}$.

a. Tahap pelaksanaan penelitian

1) Membuat digester biogas dari jerigen dengan volume 35 liter. Sambungkan kedua ujung kantong plastik masingmasing dengan selang plastik yang telah diberi pentil ban. Salah satu selang plastik tersebut disambungkan dengan jerigen (digester).

2) Menyiapkan biostarter kotoran sapi sebanyak $22 \mathrm{~kg}$ untuk 2 kali perlakuan 
dan 5 kali pengulangan.

3) Menyiapkan air biasa sebanyak 154 liter untuk 2 kali perlakuan dan 5 kali pengulangan.

4) Menyiapkan bahan dasar sampah organik sebanyak $55 \mathrm{~kg}$ untuk 2 kali perlakuan dan 5 kali pengulangan, kemudian sampah organik dicacah dengan ukuran kira-kira 5 $\mathrm{cm}$.

5) Menyiapkan starter $\mathrm{EM}_{4}$ sebanyak 450 $\mathrm{ml}$.

6) Memasukkan sampah organik yang sudah dicacah sebanyak $5 \mathrm{~kg}$ kedalam digester ke 2 dan campurkan kotoran sapi sebanyak 2 $\mathrm{kg}+$ air biasa 14 liter $+\mathrm{EM}_{4} 250 \mathrm{ml}$ untuk perlakuan ke 2 .

7) Memasukkan sampah organik yang sudah dicacah sebanyak $5 \mathrm{~kg}$ ke dalam digester ke 3 dan campurkan kotoran sapi sebanyak $2 \mathrm{~kg}+$ air biasa 14 liter tanpa penambahan starter $\mathrm{EM}_{4}$ sebagai kontrol.

8) Melakukan pengadukan setiap hari selama 7 hari supaya tidak terjadi penggumpalan didalam digester.

9) Mendiamkan sampah organik didalam digester agar gas yang diinginkan terbentuk. Pada hari ke 1 sampai hari ke 7 gas yang pertama terbentuk dibuang karena gas yang pertama merupakan gas $\mathrm{CO}_{2}$.

10) Melakukan pengamatan pada hari ke 8 dan hari selanjutnya sampai terbentuknya biogas dan apabila sudah ada tanda terbentuknya biogas lakukan uji nyala dengan menggunakan korek api.

\section{HASIL PENELITIAN}

\section{Analisis Univariat}

Berdasarkan hasil penelitian yang di lakukan pada tanggal 17 April s.d. 17 Mei 2014 di workshop jurusan Kesehatan Lingkungan Poltekkes Kemenkes Bengkulu menghasilkan data perbedaan lama waktu terbentuknya biogas, pengukuran suhu serta pengukuran $\mathrm{pH}$ (derajat keasaman), sebagai berikut:

\section{a. Lama Waktu}

Perbedaan lama waktu terbentuknya biogas dari sampah organik setelah penambahan starter $\mathrm{EM}_{4}$ sebanyak $200 \mathrm{ml}$ dan $250 \mathrm{ml}$ serta pada kelompok kontrol dengan 5 kali pengulangan, diperoleh hasil rata-rata lama waktu terbentuknya biogas seperti pada tabel berikut :

Tabel 1 Hasil perbedaan lama waktu terbentuknya Biogas

\begin{tabular}{|c|c|c|c|c|c|c|}
\hline \multirow[t]{2}{*}{ Perlakuan } & \multicolumn{5}{|c|}{ Pengulangan } & \multirow[t]{2}{*}{ Rata-rata } \\
\hline & 1 & 2 & 3 & 4 & 5 & \\
\hline $\begin{array}{c}\text { Kontrol } \\
\text { (Tanpa } \\
\text { Penambahan } \\
\mathrm{EM}_{4} \text { ) }\end{array}$ & 15 & 14 & 14 & 14 & 15 & 14,4 \\
\hline $\begin{array}{l}\text { Perlakuan } 1 \\
\text { (Penambahan } \\
\left.\mathrm{EM}_{4} 200 \mathrm{ml}\right)\end{array}$ & 13 & 12 & 13 & 13 & 12 & 12,6 \\
\hline $\begin{array}{l}\text { Perlakuan } 2 \\
(\text { Penambahan } \\
\left.\mathrm{EM}_{4} 250 \mathrm{ml}\right)\end{array}$ & 11 & 11 & 12 & 11 & 12 & 11,4 \\
\hline
\end{tabular}

Dari tabel 1 hasil penelitian menunjukkan bahwa ada perbedaan lama waktu terbentuknya biogas. pada perlakuan ke-1 dengan penambahan $\mathrm{EM}_{4}$ sebanyak 200 $\mathrm{ml}$ didapatkan rata-rata lama waktu terbentuknya biogas adalah 12,6 hari, pada perlakuan ke-2 dengan penambahan $\mathrm{EM}_{4}$ sebanyak $250 \mathrm{ml}$ didapatkam rata-rata lama waktu terbentuknya biogas adalah 11,4 hari serta pada kelompok kontrol tanpa penambahan $\mathrm{EM}_{4}$ didapatkan rata-rata waktu terbentuknya biogas 14,4 hari.

b. Suhu

Pengukuran suhu terbentuknya biogas dilakukan selama proses pembentukan biogas dari sampah organik setelah penambahan starter $\mathrm{EM}_{4}$ sebanyak $200 \mathrm{ml}$ dan $250 \mathrm{ml}$ serta pada kelompok kontrol dengan 5 kali pengulangan yaitu setiap hari diperoleh hasil rata-rata suhu terbentuknya biogas seperti 
pada tabel berikut :

$\begin{array}{lll}\text { Tabel } & 2 & \text { Hasil pengukuran suhu } \\ \text { terbentuknya Biogas }\end{array}$

\begin{tabular}{lc}
\hline \multicolumn{1}{c}{ Perlakuan } & Rata-Rata Suhu $\left({ }^{\circ} \mathrm{C}\right)$ \\
\hline Kontrol (Tanpa Penambahan & $30,7^{\circ} \mathrm{C}$ \\
$\mathrm{EM}_{4}$ ) & \\
\hline Perlakuan 1 (Penambahan & $30,7^{\circ} \mathrm{C}$ \\
$\left.\mathrm{EM}_{4} 200 \mathrm{ml}\right)$ & \\
\hline Perlakuan 2 (Penambahan & $30,7^{\circ} \mathrm{C}$ \\
$\left.\mathrm{EM}_{4} 250 \mathrm{ml}\right)$ & \\
\hline
\end{tabular}

Tabel 2 hasil penelitian menunjukan bahwa pengukuran suhu pada perlakuan ke-1 dengan penambahan $\mathrm{EM}_{4}$ sebanyak $200 \mathrm{ml}$ didapatkan suhu rata-ratanya adalah $30,7^{\circ} \mathrm{C}$, pada perlakuan ke-2 dengan penambahan $\mathrm{EM}_{4}$ sebanyak $250 \mathrm{ml}$ didapatkan suhu rata-ratanya adalah $30,7^{\circ} \mathrm{C}$ serta pada kelompok kontrol tanpa penambahan $\mathrm{EM}_{4}$ didapatkan suhu rata-ratanya adalah $30,7^{\circ} \mathrm{C}$.

c. Nilai pH (derajat keasaman).

Pengukuran $\mathrm{pH}$ (derajat keasaman) dilakukan selama proses pembentukan biogas dari sampah organik setelah penambahan starter $\mathrm{EM}_{4}$ sebanyak $200 \mathrm{ml}$ dan $250 \mathrm{ml}$ serta pada kelompok kontrol dengan 5 kali pengulangan yaitu setiap hari, diperoleh hasil rata-rata $\mathrm{pH}$ (derajat keasaman) biogas seperti pada tabel berikut :

Tabel 3 Hasil pengukuran pH terbentuknya Biogas

\begin{tabular}{lc}
\hline \multicolumn{1}{c}{ Perlakuan } & Rata-Rata pH \\
\hline Kontrol (Tanpa Penambahan & 6,62 \\
$\mathrm{EM}_{4}$ ) & \\
\hline Perlakuan 1 (Penambahan & 6,46 \\
$\left.\mathrm{EM}_{4} 200 \mathrm{ml}\right)$ & \\
\hline Perlakuan 2 (Penambahan & 6,58 \\
$\left.\mathrm{EM}_{4} 250 \mathrm{ml}\right)$ & \\
\hline
\end{tabular}

Tabel 3 hasil penelitian menunjukan bahwa pengukuran nilai $\mathrm{pH}$ (derajat keasaman) pada perlakuan ke-1 dengan penambahan $\mathrm{EM}_{4}$ sebanyak $200 \quad \mathrm{ml}$ didapatkan $\mathrm{pH}$ rata-ratanya adalah 6,46 , pada perlakuan ke-2 dengan penambahan $\mathrm{EM}_{4}$ sebanyak $250 \mathrm{ml}$ didapatkan $\mathrm{pH}$ rata-ratanya adalah 6,58 serta pada kelompok kontrol tanpa penambahan $\mathrm{EM}_{4}$ didapatkan $\mathrm{pH}$ rataratanya adalah 6,62 .

\section{Analisis Bivariat}

\section{a. Uji Anova Satu Arah (One Way Anova)}

Uji ini digunakan untuk menguji sebuah rancangan lebih dari dua untuk mengetahui apakah ada perbedaan lama waktu terbentuknya biogas dari sampah organik setelah penambahan starter $\mathrm{EM}_{4}$ sebanyak $200 \mathrm{ml}$ dan $250 \mathrm{ml}$ serta pada kelompok kontrol.

Tabel 4 Hasil Uji One Way Anova Perbedaan Lama Waktu Terbentuknya Biogas

\begin{tabular}{ccccc}
\hline $\begin{array}{c}\text { Variabel } \\
\text { Perlakuan }\end{array}$ & Mean & SD & $95 \% \mathrm{Cl}$ & $\begin{array}{c}\mathrm{P} \\
\text { Value }\end{array}$ \\
\cline { 1 - 4 } Kontrol & 14,40 & 0,548 & $\begin{array}{c}13,72- \\
15,08\end{array}$ & \\
\cline { 1 - 3 } $\mathrm{EM}_{4} 200 \mathrm{ml}$ & 12,60 & 0,548 & $\begin{array}{c}11,92- \\
13,28\end{array}$ & 0,000 \\
\cline { 1 - 3 } $\mathrm{EM}_{4} 250 \mathrm{ml}$ & 11,40 & 0,548 & $\begin{array}{c}10,72- \\
12,08\end{array}$ & \\
\hline
\end{tabular}

Dari tabel 4 menyatakan nilai $\mathrm{p}: 0,000<$ 0,05 , artinya ada perbedaan lama waktu terbentuknya biogas sampah organik dengan penambahan $\mathrm{EM}_{4}$ sebanyak $200 \mathrm{ml}$ dan 250 $\mathrm{ml}$ serta pada kelompok kontrol.

Selanjutnya untuk mengetahui perbedaan lama waktu terbentuknya biogas sampah organik dengan penambahan $\mathrm{EM}_{4}$ sebanyak $200 \mathrm{ml}$ dan $250 \mathrm{ml}$ serta pada kelompok kontrol, dilakukan uji Bonferroni. Hasil uji Bonferroni dapat dilihat sebagai berikut :

Tabel 5 Hasil Uji Bonferroni Perbedaan 
Lama Waktu Terbentuknya Bioga

\begin{tabular}{cccc}
\hline Perlakuan & & $\begin{array}{c}\text { Rata-Rata } \\
\text { Beda (Hari) }\end{array}$ & P value \\
\hline Kontrol & $\mathrm{EM}_{4} 200$ & 1,800 & 0,001 \\
& $\mathrm{ml}$ & & \\
\hline & $\mathrm{EM}_{4} 250 \mathrm{ml}$ & 3,000 & 0,000 \\
\hline $\mathrm{EM}_{4} 200 \mathrm{ml}$ & $\mathrm{EM}_{4} 250$ & 1,200 & 0,014 \\
& $\mathrm{ml}$ & & \\
\hline
\end{tabular}

Tabel 5 menunjukan bahwa rata-rata beda lama waktu terbentuknya biogas antara kontrol dan perlakuan ke-1 dengan penambahan $\mathrm{EM}_{4}$ sebanyak $200 \mathrm{ml}$ adalah 2 hari. Secara statistik didapatkan $\mathrm{p}=0,001<$ 0,05 sehingga dapat dikatakan ada perbedaan lama waktu terbentuknya biogas pada perlakuan ke-1 dengan penambahan $\mathrm{EM}_{4} 200$ $\mathrm{ml}$ dan kelompok kontrol. Rata-rata beda lama waktu terbentuknya biogas antara kelompok kontrol dan perlakuan ke-2 dengan penambahan $\mathrm{EM}_{4} 250 \mathrm{ml}$ adalah 3 hari.

Secara analisis statistik $\mathrm{p}=0,000<0,05$ sehingga ada perbedaan lama waktu terbentuknya biogas pada perlakuan ke-2 dengan penambahan $\mathrm{EM}_{4} 250 \mathrm{ml}$ dan kelompok kontrol.

Pada perlakuan ke-1 penambahan $\mathrm{EM}_{4}$ $200 \mathrm{ml}$ dan perlakuan ke-2 penambahan $\mathrm{EM}_{4}$ $250 \mathrm{ml}$, lama waktu terbentuknya biogas adalah 1 hari. Secara statistik $p=0,014<0,05$ maka ada perbedaan lama waktu terbentuknya biogas pada perlakuan ke-1 dengan penambahan $\mathrm{EM}_{4} 200 \mathrm{ml}$ dan perlakuan ke-2 dengan penambahan $\mathrm{EM}_{4} 250 \mathrm{ml}$.

Dapat disimpulkan bahwa ada perbedaan yang bermakna terhadap lama waktu terbentuknya biogas sampah organik terhadap tiga kelompok perlakuan yaitu penambahan $\mathrm{EM}_{4}$ sebanyak $200 \mathrm{ml}$ dan $250 \mathrm{ml}$ serta pada kelompok kontrol, dan diantara ketiga perlakuan yang paling efektif dalam mempercepat pembentukan biogas adalah pada perlakuan ke-2 dengan penambahan $\mathrm{EM}_{4}$ sebanyak $250 \mathrm{ml}$.

\section{PEMBAHASAN}

Berdasarkan penelitian yang dilakukan oleh peneliti pada tanggal 17 April s.d. 17 Mei 2014 diperoleh hasil penelitian untuk perbedaan lama waktu terbentuknya biogas dari sampah organik setelah penambahan starter $\mathrm{EM}_{4}$ sebanyak $200 \mathrm{ml}$ dan $250 \mathrm{ml}$ serta pada kelompok kontrol dengan 5 kali pengulangan, menghasilkan data nilai perbedaan lama waktu terbentuknya biogas secara deskriptif dan analitik.

Penelitian ini dilakukan untuk mengetahui lama waktu terbentuknya biogas dari sampah organik setelah penambahan starter $\mathrm{EM}_{4}$ sebanyak $200 \mathrm{ml}$ dan $250 \mathrm{ml}$ serta pada kelompok kontrol lama. Sampah organik terlebih dahulu dicacah hingga menjadi halus kemudian dilanjutkan sesuai dengan perlakuan untuk mengetahui perlakuan yang paling cepat membentuk biogas.

Hasil uji One Way Anova diketahui bahwa penambahan $\mathrm{EM}_{4}$ sebanyak $250 \mathrm{ml}$ pada perlakuan ke-2 sangat berpengaruh terhadap efektifitas lama waktu terbentuknya biogas sampah organik. Pada penelitian ini peneliti membedakan dosis $\mathrm{EM}_{4}$ yang digunakan agar dapat digunakan sebagai pembanding pada masing-masing perlakuan serta sebagai cara untuk menentukan dosis $\mathrm{EM}_{4}$ yang paling efektif dalam lama waktu terbentuknya biogas sampah organik.

Untuk mengetahui perbedaan efektifitas dosis $\mathrm{EM}_{4}$ terhadap lama waktu terbentuknya biogas sampah organik, dilakukan uji Bonferroni sehingga diperoleh hasil bahwa perlakuan ke-2 dengan sampah organik sebanyak $5 \mathrm{~kg}$ yang dicacah, dengan penambahan biostarter kotoran sapi $2 \mathrm{~kg}$ dan $\mathrm{EM}_{4} 250 \mathrm{ml}$ yang paling efektif terhadap lama waktu terbentuknya biogas.

Penelitian ini sejalan dengan penelitian yang telah dilakukan oleh Famor Haryawan (2012), yng berjudul "Efektifitas penambahan urine $+\mathrm{EM}_{4}$ dan air biasa $+\mathrm{EM}_{4}$ pada sampah organik terhadap lama waktu terbentuknya 
biogas". Dengan hasil lama waktu terbentuknya biogas yang terbuat dari urine lebih cepat dengan penambahan $\mathrm{EM}_{4}$ rata-rata membutuhkan 27,56 hari untuk terbentuknya gas, sedangkan biogas yang terbuat dari air biasa da $\mathrm{EM}_{4}$ rata-rata membutuhkan 32,67 hari untuk terbentuknya gas. Pada penelitian ini peneliti memilih sampah organik sebagai bahan dasar pembuatan biogas sebanyak $5 \mathrm{~kg}$ dengan penambahan biostarter kotoran sapi sebanyak $2 \mathrm{~kg}$ dan air sebanyak 14 liter dengan dosis $\mathrm{EM}_{4}$ bervariasi yaitu sebanyak $200 \mathrm{ml}$ dan $250 \mathrm{ml}$.

Proses fermentasi atau proses pencernaan mengacu pada proses berbagai reaksi dan interaksi yang terjadi di antara bakteri metanogenenik dan non- metaogenik serta bahan yang diumpankan ke dalam digester sebagai input. Proses fisika-kimia yang kompleks dan proses biologis yang.melibatkan berbagai faktor dan tahapan bentuk. Penghancuran input yang merupakan bahan organik dicapai dalam tiga tahapan, yaitu hidrolisa, acidification, dan methanization (Suryani, 2008).

Pada penelitian ini peneliti melakukan variasi dosis $\mathrm{EM}_{4}$ yaitu sebanyak $200 \mathrm{ml}$ dan $250 \mathrm{ml}$ untuk mempercepat proses terbentuknya biogas dengan bahan dasar sampah organik. Diperoleh hasil bahwa diperoleh hasil bahwa perlakuan ke-2 dengan sampah organik sebanyak $5 \mathrm{~kg}$ yang dicacah, dengan penambahan biostarter kotoran sapi 2 $\mathrm{kg}$ dan $\mathrm{EM}_{4} 250 \mathrm{ml}$ yang paling efektif terhadap lama waktu terbentuknya biogas karena semakin banyak starter yang digunakan maka akan semakin cepat pula pembentukan biogas.

Berdasarkan hasil penelitian yang dilakukan peneliti bahwa lebih efektif untuk pembuatan biogas adalah perlakuan ke-2 yaitu dengan penambahan $\mathrm{EM}_{4}$ sebanyak 250 $\mathrm{ml}$ dengan penambahan biostarter $\mathrm{EM}_{4}$ dapat menguraikan bahan organik dan mempercepat proses fermentasi sehingg biogas akan lebih cepat terbentuk serta dilakukan pengadukan setiap hari sehingga tidak terjadi penggumpalan dan pembentukan biogas tidak terhambat. Sedangkan pada perlakuan ke-1 dengan penambahan $\mathrm{EM}_{4}$ sebanyak $200 \mathrm{ml}$ dan pada kelompok control tanpa penambahan biostarter $\mathrm{EM}_{4}$ kurang efektif dalam pembentukan biogas karena membutuhkan waktu tang lebih lama dibandingkan dengan perlakuan ke-2.

\section{KESIMPULAN}

Berdasarkan hasil penelitian tentang pemanfaatan sampah organik sebagai bahan dasar pembuatan biogas dapat disimpulkan, sebagai berikut :

1. Lama waktu terbentuknya biogas sampah organik yang dicacah dengan penambahan biostarter kotoran sapi $2 \mathrm{~kg}$ dan $\mathrm{EM}_{4} 200 \mathrm{ml}$ adalah 13 hari.

2. Lama waktu terbentuknya biogas sampah organik yang dicacah dengan penambahan biostarter kotoran sapi $2 \mathrm{~kg}$ dan $\mathrm{EM}_{4} 250 \mathrm{ml}$ adalah 11 hari.

3. Ada perbedaan lama waktu terbentuknya biogas sampah organik yang dicacah dengan penambahan biostarter kotoran sapi $2 \mathrm{~kg}, \mathrm{EM}_{4}$ sebanyak $200 \mathrm{ml}$ dan 250 $\mathrm{ml}$.

\section{DAFTAR PUSTAKA}

Alex S, 2012. Pengelolahan Sampah Organik (Sayuran) Menjadi Biogas Dapat Mengurangi Masalah Sampah. Bandung; Penebar Swadaya.

BPS, 2013. Data Jumlah Penduduk Tahun 2013. Indonesia ; BPS

Chandra, 2012. Sampah Sumber Penularan Penyakit. Jakarta ; Rineka Cipta Sri

Haryan, Famor.2012. Efektifitas Penambahan Urine + EM4 Dan Air Biasa + EM4 Pada Sampah Organik Terhadap Lama Waktu Terbentuknya Biogas. Karya Tulis Ilmiah (KTI) , Poltekkes Kemenkes. Bengkulu Bengkulu.

http//:www.wikipedia.com. Diunggah 1 Maret 2014 
J. Sugito, 2007. Komposisi Kotoran Sapi. Bandung; Penebar Swadaya.

Kaltschamitt, 2011. Komposisi Biogas. http//:www.Wikipedia.com. Diunggah 1 Maret 2014

Karimin, 2012. Pemanfaatan Kotoran Sapi Menjadi Biogas. Malang;Pertenakan Kita, 2012

Martoni, Harta, 2013. Pemanfaatan Enceg Gondok (Eichhornia Crassipes) Sebagai Alternatif Bahan Dasar Pembuatan Biogas. Karya Tulis Ilmiah (KTI), Poltekkes Kemenkes Bengkulu. Bengkulu.

Mualim, dkk. 2003. Buku Pedoman Penulisan Karya Tulis Ilmiah Jurusan Kesehatan Lingkungan Poltekkes Kemenkes Bengkulu Tahun 2013. Poltekkes Kemenkes Bengkulu. Bengkulu

Notoatmodjo, Soekidjo. 2010. Metodologi Penelitian Kesehatan. Rineka Cipta. Jakarta.

Nurcahyo, 2003. Reaksi Kimia Pada Biogas. Bandung ; Penebar Swadaya.

Para Ahli, 2006. Limbah Kotoran Sapi Sebagai Bahan Biogas. Diakses dari kris-smile.bogspot.com tanggal 10 Juli 2014.

Rochim, 2010. Proses Penguraian Sampah Organik. http//:www.wordpress.com. Diunggah 1 Maret 2014

Sinamora, Suhut. 2008 Membuat Biogas Pengganti Bahan Bakar Minyak Dan Gas Dari Kotoran Sapi Ternak. Penerbit : PT. Agro Media Pustaka.

Setiawan, 2007. Manfaatkan Kotoran Ternak, Bogor : Penebar Swadaya

Setiawan, 2007. Model-model Alat Penghasil Biogas. Yogyakarta ; Cipta Pustaka

Soewarno.2009. Pengolahan Sampah Organik Untuk Memproduksi Biogas Sebagai Energi Terbarukan. Penerbit : PT. Agro Media Pustaka

Sugiono, 2006. Metode Penelitian Kuantitatif Kualitatif dan R\&D. Bandung;Alfabeta

Suryani, 2008. Tahapan Proses Fermentasi Pada Pembentukan Biogas.

Suyitno, 2010. Pemanfaatan Kotoran Sapi
Sebagai Bahan Pembuatan Biogas.

Yogyakarta ; Jurnal Pertanian

Wahyuni, 2011. Masalah Krisis BBM di Indonesia. Jakarta; Alfabeta

Wahyuni, Sri. 2011. Menghasilkan Biogas Dari Aneka Limbah. Jakarta Selatan : PT Agro Media Pustaka. 